twice in over 500 punctures and caused no disability. The complication is worthy of note, however, since failure to recognise that it may be due to the venepuncture may lead to a fruitless search for other causes.

${ }^{1}$ Yoffa, D, Lancet, 1965, 2, 614.

2 Macaulay, M B, and Wright, J S, British Medical fournal, 1970, 4, 207.

3 Epstein, E J, and Coulshed, N C, British Heart fournal, 1971, 33, 658.

${ }^{4}$ Walker, M M, and Sanders, R C, Anaesthesia, 1969, 24, 453.

${ }^{5}$ Land, R E, Archives of Surgery, 1971, 102, 178.

Liverpool Regional Cardiac Centre, Sefton General Hospital, Liverpool 15

E J EPSTEIN, MD, MRCP, consultant cardiologist

M S A QUERESHI, MB, MRCP, registrar (present appointment: senio medical registrar, Crumpsall Hospital, Manchester M8 6RB)

J S WRIGHT, MD, MRCP, senior registrar (present appointment: consultan cardiologist, Lancashire Area Health Authority, Victoria Hospital, Blackpool FY3 8NR)

\section{Small infant thymus in cases of fatal feto-maternal transfusion}

The laboratory diagnosis of massive feto-maternal haemorrhage was formerly made on blood group-serological investigations and quantitative estimations of fetal haemoglobin. Since the introduction of the simple and reliable Kleihauer technique ${ }^{1}$ for identifying individual fetal erythrocytes in maternal blood many more cases have been diagnosed. The severity of the resulting anaemia and haemorrhagic shock are often emphasised yet relatively few fatal cases have been reported, and fewer still in which the necropsy findings were detailed. We report three cases in which the thymus was notably small.

\section{Case reports}

At the necropsy of an infant with a rather dramatic history of transplacental blood loss we were impressed by the smallness for the thymus. Reviewing our necropsy records we found two other cases of infant death from massive feto-maternal transfusion in which the thymus was remarkably small. The essential clinical and necropsy findings in these three cases are shown in the table. In a fourth case, which is not included, the diagnosis of massive feto-maternal transfusion could only be suspected because the mother's blood was not available for Kleihauer testing, but here too the thymus was smaller than expected.

\section{Comment}

The low weight of the thymus in these three cases suggests that this may be a regular feature of fetal transplacental blood loss. In a report ${ }^{2}$ of two other cases the thymus is described as "exhausted," although weights are not stated. Thymic exhaustion may be a result of chronic fetal distress such as had been seen in a non-fatal case of massive fetomaternal transfusion. ${ }^{3}$ We believe that the hypoxia resulting from anaemia is responsible, but other factors cannot be excluded. One of us (HGK) has found the thymus to weigh less than was expected in many cases of perinatal death from anaemia regardless of whether it stemmed from haemolysis, as in $\mathrm{Rh}$ incompatibility, from traumatic blood loss-for example, from ruptured placental blood vessels-or (in the donor twin) from twin transfusion. In none of our cases was there a maternal reaction to the infusion of "uncross-matched" blood. ${ }^{4}$ Indeed, the "major" blood groups of mother and infant were identical in all three.

The thymus should be weighed in every perinatal necropsy and the weight correlated with the total body weight. Apart from cases of anaemia, the thymus may be lighter than expected in a variety of conditions ranging from a malformation complex of the third and fourth branchial arches (Di George's syndrome) to intrauterine malnutrition (chronic placental insufficiency) and including intrauterine infection and congenital immune deficiency. When a small thymus cannot readily be attributed to one of these causes a maternal Kleihauer test should be done-as it should also in all newborn infants suffering from anaemia or shock, or both, for which the cause is not apparent.

We do not know of any investigations into the functional efficiency of the thymus in infants surviving after massive feto-maternal transfusion. A depression of cell-mediated immunity might be expected. Reduced humoral immune reactivity, due to loss of IgG, has been found in donor twins of feto-fetal transfusions. ${ }^{5}$ We have no reason to expect differently in feto-maternal transfusion even though nature does not provide a conveniently available control.

${ }^{1}$ Kleihauer, E, Braun, H, and Betke, K, Klinische Wochenschrift, 1957, 35, 637.

2 Van de Putte, I, Renaer, M, and Vermylen, C, Americanfournal of Obstetrics and Gynecology, 1972, 114, 850.

${ }^{3}$ Lunay, G G, Edwards, R F, and Thomas, D B, British Medical fournal, $1970,2,218$.

${ }^{4}$ Glasser, L, West, J H, and Hagood, R M, Transfusion, 1970, 10, 322.

${ }^{5}$ Bryan, E M, and Slavin, B, Archives of Disease in Childhood, 1974, 49, 908.

6 Potter, E L, Pathology of the Fetus and Infant, 2nd edn, p 14. Chicago, Year Book Publishers, 1961.

Babies' Special Care Unit and the Department of Pathology, The Maternity Hospital at Leeds, Leeds LS2 9LW

J ELLIS, MB, MRCP, paediatric registrar (now tutor in child health, University of Manchester)

H G KOHLER, MD, FRCPATH, consultant pathologist

Clinical and necropsy findings in three cases of fatal feto-maternal transfusion

\begin{tabular}{|c|c|c|c|c|c|c|c|c|c|c|c|c|c|}
\hline \multirow{2}{*}{$\begin{array}{l}\text { Case } \\
\text { No }\end{array}$} & \multicolumn{2}{|c|}{ Blood group } & \multirow{2}{*}{$\begin{array}{c}\text { Gesta- } \\
\text { tional } \\
\text { age } \\
\text { (weeks) }\end{array}$} & \multirow{2}{*}{$\left|\begin{array}{c}\text { Body } \\
\text { Weight } \\
(\mathrm{g})\end{array}\right|$} & \multirow{2}{*}{$\begin{array}{c}\text { Initial } \\
\mathrm{Hb} \\
(\mathrm{g} / \mathrm{dl})\end{array}$} & \multirow{2}{*}{$\begin{array}{l}\text { Kleihauer } \\
\text { count or } \\
\% \text { of fetal } \\
\text { cells }\end{array}$} & \multirow{2}{*}{$\begin{array}{c}\text { Trans- } \\
\text { placental } \\
\text { loss } \\
\text { (ml) } \\
\end{array}$} & \multirow{2}{*}{ Treatment } & \multirow{2}{*}{$\begin{array}{l}\text { Survival } \\
\text { time } \\
\text { (h) }\end{array}$} & \multicolumn{3}{|c|}{$\begin{array}{l}\text { Thymus weight } \\
\text { (g) }\end{array}$} & \multirow{2}{*}{$\begin{array}{l}\text { Cause of } \\
\text { death and } \\
\text { necropsy }\end{array}$} \\
\hline & Mother & Infant & & & & & & & & Expected ${ }^{*}$ & Actual & $\begin{array}{c}\% \text { of } \\
\text { expected }\end{array}$ & \\
\hline 1 & $\overline{A, R h(D) n e g}$ & $\mathrm{~A}, \mathrm{Rh}(\mathrm{D}) \mathrm{neg}$ & 40 & 2685 & $5 \cdot 0$ & $4 \%$ & 200 & $\begin{array}{l}\text { Transfusion } \\
75 \mathrm{ml} \text { at }\end{array}$ & 72 & 9.5 & 3.5 & 38 & $\begin{array}{l}\text { Circulatory } \\
\text { failure }\end{array}$ \\
\hline 2 & $\mathrm{O}, \mathrm{Rh}(\mathrm{D})$ neg & O,Rh(D)neg & 41 & 3860 & 11.0 & $\begin{array}{l}5750 / 50 \\
\text { LPF† }\end{array}$ & 150 & $\begin{array}{l}4 \text { hours } \\
\text { Exchange } \\
\text { transfusion } \\
110 \mathrm{ml}\end{array}$ & $12 \frac{3}{4}$ & $13 \cdot 0$ & 4.75 & 36 & $\begin{array}{l}\text { Circulatory } \\
\text { failure. } \\
\text { Slight bilateral } \\
\text { intraventricular }\end{array}$ \\
\hline 3 & O,Rh(D)pos & O,Rh(D)pos & 42 & 3420 & $2 \cdot 8$ & $6 \%$ & 300 & $\begin{array}{l}\text { Transfusion } \\
600 \mathrm{ml} . \\
\text { Exchange } \\
\text { transfusions } \\
\text { of } 100 \mathrm{ml} \\
\text { and of } \\
140 \mathrm{ml} \text {. } \\
\text { Venesection } \\
30 \mathrm{ml}\end{array}$ & $7 \frac{1}{2}$ & 11.6 & $4 \cdot 4$ & 38 & $\begin{array}{l}\text { haemorrhage } \\
\text { Circulatory } \\
\text { failure. } \\
\text { Intrapartum } \\
\text { fetal distress. } \\
\text { Cord twice } \\
\text { around neck. } \\
\text { Pallor of all } \\
\text { organs }\end{array}$ \\
\hline
\end{tabular}

*Expected weights according to Potter."

$+\mathrm{LPF}=$ low power field. 